\title{
PENGARUH PENYULUHAN TERHADAP TINGKAT PENGETAHUAN TENTANG CARA PEMERIKSAAN PAYUDARA SENDIRI PADA IBU-IBU PKK
}

\author{
(Di RW 05 RT 08 Kelurahan Sawunggaling Kecamatan Wonokromo Surabaya)
}

\author{
Marcellina Rasemi Widayanti*, Maria Santrisna Wulu** \\ STIKES Katolik St. Vincentius A Paulo Surabaya \\ Marcellina_raswi@yahoo.co.id
}

\begin{abstract}
ABSTRAK
Pemeriksaan payudara sendiri (SADARI) merupakan pemeriksaan dengan melihat dan memeriksa perubahan payudaranya sendiri setiap bulan sehingga kelainan dapat dideteksi secara dini. Fenomena yang di temukan oleh peneliti pada ibu-ibu PKK di RT 08 RW 05 Kelurahan Sawunggaling Kecamatan Wonokromo Surabaya, beberapa ibu-ibu belum mengenal tentang cara pemeriksaan payudara sendiri dan tidak pernah melakukan cara pemeriksaan payudara sendiri (SADARI). Tujuan penelitian ini adalah untuk menganalisis pengaruh penyuluhan terhadap tingkat pengetahuan (tahu) mengenai pemeriksaan payudara sendiri (SADARI) pada ibu-ibu PKK. Desain penelitian ini adalah pra eksperimental dengan rancangan one-group pra-post test design dan populasi penelitian ini adalah ibu-ibu PKK di RW 05 RT 08 Kelurahan Sawunggaling Kecamatan Wonokromo Surabaya dan menggunakan simple random sampling didapatkan sebanyak 33 responden berdasarkan kriteria inklusi. Variabel independen dalam penelitian ini adalah penyuluhan dan variabel dependennya adalah tingkat pengetahuan. Instrument pengumpulan data menggunakan kuesioner. Hasil penelitian didapatkan bahwa tingkat pengetahuan responden sebelum diberikan penyuluhan didapatkan hasil lebih dari 50\% (58\%) responden memiliki tingkat pengetahuan cukup dan setelah dilakukan penyuluhan didapatkan lebih dari $50 \%(61 \%)$ responden memiliki tingkat pengetahuan baik. Hasil uji statistik Wilcoxon dengan tingkat signifikan $\alpha=0,005$ didapatkan harga $\mathrm{p}=0,000$ dan nilai Zhitung $=-3,752>$ Ztabel $= \pm 1,96$. Oleh karena harga $\mathrm{p}<\alpha$, maka $\mathrm{H} 0$ ditolak dan $\mathrm{H} 1$ diterima artinya ada pengaruh penyuluhan terhadap tingkat pengetahuan tentang cara pemeriksaan payudara sendiri. Berdasarkan hasil penelitian, saran peneliti kepada ibu kader kesehatan untuk bekerja sama dengan petugas kesehatan dari Puskesmas Jagir dalam memberikan penyuluhan kesehatan agar dapat meningkatkan pengetahuan tentang cara pemeriksaan payudara sendiri (SADARI).
\end{abstract}

Kata kunci: Penyuluhan, Tingkat Pengetahuan, Pemeriksaan Payudara Sendiri

\begin{abstract}
Breast self-examination (BSE) is breast examination conducted it self with the view and examine her own breasts every month to detect abnormalities early. Phenomenon that found a researcher of PKK women in RT 08, some are mothers did not yet know about the examination own breast and never have a own breast. The purpose of this research is to analyze the influence of counseling to the knowledge of examination own breast in PKK women. The design of this research is Pre Experimental One-Group Pra Post Test Design and population of this research is PKK and it use simple random sampling obtained as many 33 respondents based on the criteria inclusion. An independent variable in this research is counseling and the variable dependent is the level of knowledge. the Instrument data collection uses a questionnaire. The results of the study got that level knowledge was before it was given counseling as many as $58 \%$ respondents has a knowledge moderate level and through counseling $61 \%$ respondents having a level of knowledge of good. The results of statistical tests wilcoxon with a significant degree $\alpha=0,005$ obtained the price $p=0,000$ and $\mathrm{Z}$ count $>\mathrm{Z}$ tabel. By as the price of $\mathrm{p}<\alpha$, so $\mathrm{HO}$ were rejected and $\mathrm{H} 1$ received mean there are influence counseling On the level of the knowledge about how examination own breast. Based on the results of the study the researchhers give sugesst to volunter make collaborate with Jagir Human Health Center to give health infotmation every meeting for women who have not received counseling to increase the knowledge of examination own breast.
\end{abstract}

Keywords: Counseling, The Knowledge, Realize 


\section{Pendahuluan}

Pemeriksaan payudara sendiri merupakan pemeriksaan dengan melihat dan memeriksa perubahan payudaranya sendiri setiap bulan. Dengan melakukan pemeriksaan secara teratur akan diketahui adanya benjolan atau masalah lain sejak dini walaupun masih berukuran kecil sehingga lebih efektif untuk di obati (Depkes,2009, hal :14). Manfaat periksa payudara sendiri (SADARI) adalah untuk mengetahui secara dini adanya tumor atau benjolan pada payudara sehingga dapat mengurangi tingkat kematian karena penyakit kanker tersebut. Keuntungan dari deteksi dini bermanfaat untuk meningkatkan kemungkinan harapan hidup pada wanita penderita kanker payudara. Fenomena yang di temukan oleh peneliti pada ibu-ibu PKK di RT 08, beberapa ibu-ibu belum mengenal tentang cara pemeriksaan payudara sendiri dan ada yang mengatakan tahu tentang cara pemeriksaan payudara sendiri dari penyuluhan tentang pengobatan kanker payudara menggunakan obat herbal tetapi jarang bahkan tidak pernah melakukan pemeriksaan payudara sendiri.

Menurut WHO (World Health Organization) tahun 2010 memperkirakan bahwa angka kejadian kanker payudara adalah 11 juta dan tahun 2030 akan bertambah menjadi 27 juta kematian akibat kanker. Angka penderita kanker payudara di indonesia pada tahun 2010 menurut Departemen Kesehatan sebesar 876.665 orang dengan rat-rata penderita kanker payudara di indonesia adalah 10 dari 100.000 perampuan. Kejadian kanker payudara di Indonesia meningkat dengan prosentase $60 \%$ dari tahun 2004 sampai dengan 2007 dan sebagian besar kasus ini terdeteksi pada stadium lanjut sehingga pada umumnya berakhir dengan kematian. Kanker payudara dapat dideteksi secara dini. Upaya yang dapat dilakukan salah satunya dengan melakukan pemeriksaan payudara sendiri (SADARI). Benjolan payudara 95\% ditemukan oleh wanita itu sendiri, sehingga penting dilakukan SADARI. Hasil survey yang dilakukan pada tangal 27 Januari 2016 pada ibu-ibu PKK di RW 05 RT 08 Kelurahan Sawunggaling, dari 10 orang ibu, 40\% (4 orang) mengatakan tidak tahu tentang SADARI, $60 \%$ (6 orang) tahu tentang SADARI. Dari $60 \%$ (6 orang) yang tau tentang SADARI, 20\% (2 orang) mengetahui teknik dan sering melakukan, 30\% (3 orang) tidak terlalu memahami teknik dan jarang melakukan, $1 \%$ (1 orang) mengetahui tetapi tidak melakukan SADARI.

Faktor yang mempengaruhi pengetahuan adalah pendidikan. Pendidikan tersebut dapat diberikan melalui penyuluhan kesehatan informasi (Mubarak,2012, hal :8384). Untuk memperoleh suatu informasi dapat membantu mempercepat seseorang untuk memperoleh pengetahuan yang baru (Mubarak,2007, hal :30). Pengetahuan akan informasi mengenai SADARI akan mempengaruhi tindakan yang dilakukan seseorang, apabila informasi yang diperoleh individu bersifat baik maka tindakan yang akan dilakukannya pun akan baik. Kurang pengetahuan disebabkan oleh minimnya informasi tentang SADARI yang berakibat tidak pernah melakukan pemeriksaan dini pada payudara. Bila terdapat benjolan di sekitar payudara maka kemungkinan benjolan tersebut tidak terdeteksi dengan cepat. Bila benjolan tesebut dibiarkan tanpa adanya pemeriksaan maka lama kelamaan benjolan semakin membesar yang berakibat jatuh pada stadium lanjut sehingga terjadinya penyakit kanker payudara bahkan sampai kematian. Jika pemeriksaan SADARI tidak dilakukan maka sesuatu yang abnormal dalam payudara tidak dapat terdeteksi dan saat diketahui hal tersebut melalui pemeriksaan dokter, pencegahan atau pengobatan yang dilakukan pun sudah terlambat dan untuk penyembuhan akan membutuhkan jangka waktu yang lama serta biaya yang besar.

Tujuan dari penelitian ini adalah Untuk mengetahui pengaruh penyuluhan tingkat pengetahuan cara pemeriksaan payudara sendiri (SADARI) pada ibu-ibu PKK di RW 05 RT 08 Kelurahan Sawunggaling Kecamatan Wonokromo Surabaya.

\section{Metode}

Metode penelitian ini pra-eksperimental dengan pendekatan one group pre-post test desgn. Varabel independent adalah penyuluhan tentang SADARI dan variabel dependen tingkat pengetahuan. Populasi yang digunakan adalah seluruh ibu-ibu PKK di RW 05 RT 08 yang memenuhi kriteria inklusi: hadir saat penelitian dan bersedia menjadi responden. Sampel diambil dengan 
simple random sampling sejumlah 33 responden.

Penelitian ini dilakukan di RW 05 RT 08 Kelurahan Sawunggaling Kecamatan Wonokromo Surabaya 11 Mei 2016. Proses pengambilan data dengan memberikan kuesioner. Data dianalisis dengan membandingkan tingkat pengetahuan tentang cara pemeriksaan payudara sendiri (SADARI) sebelum dan sesudah diberikan penyuluhan. Uji statistik yang digunakan adalah uji Wilcoxon dengan tingkat signifikan $\alpha=0,05$.

\section{Hasil}

Tabel 1. Karakteristik Responden

\begin{tabular}{llll}
\hline NO & KRITERIA & N & \% \\
\hline 1 & Usia & & \\
& 20-40 & 16 & 48,48 \\
& $41-60$ & 17 & 51,52 \\
2 & Pekerjaan & & \\
& Bekerja & 6 & 18,18 \\
& Tidak bekerja & 27 & 81,82 \\
3 & Pendidikan & & \\
& SD & 4 & 12,12 \\
& SMP & 6 & 18,18 \\
& SMA & 19 & 57,58 \\
& PT & 4 & 12,12 \\
& Informasi & & \\
& Pernah & 20 & 60,61 \\
& Tidak pernah & 13 & 39,39 \\
& Sumber & & \\
informasi & & \\
& Petugas & 9 & 27,27 \\
& kesehatan & & \\
& Media & 4 & 12,12 \\
& elektronik & & \\
Media cetak & 3 & 9,09 \\
& Teman & 4 & 12,12 \\
\hline
\end{tabular}

Tabel 1 menunjukkan bahwa rata-rata usia responden adalah 41,58 tahun. Ditinjau dari tingkat pekerjaan, sebanyak 27 responden tidak bekerja. Ditinjau dari tingkat pendidikan, sebanyak 19 responden memiliki tingkat pendidikan tinggi (SMA). Bila ditinjau dari pernah memberikan informasi sebanyak 20 responden pernah mendapatkan informasi dan apabila ditinjau dari sumber informasi sebanyak 13 responden tidak pernah mendapatkan informasi.

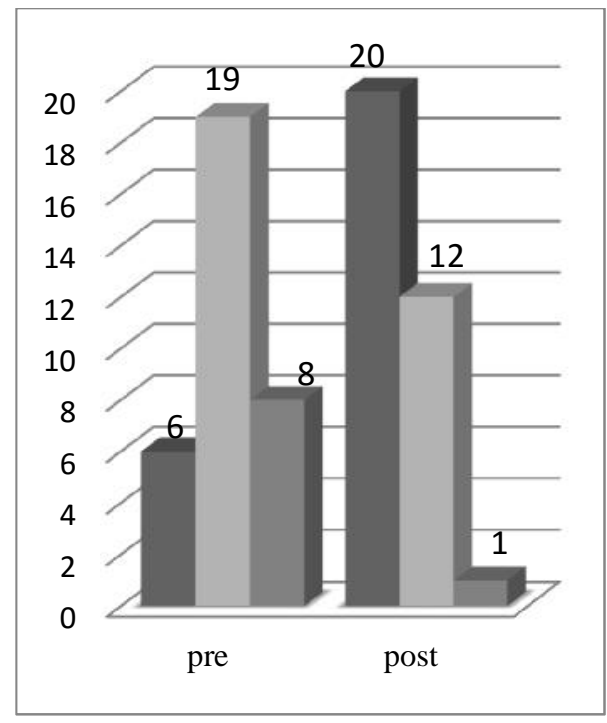

Diagram 1: Karakteristik Responden Berdasarakan Tingkat Pengetahuan (Tahu) Ibu-Ibu PKK Tentang Cara Pemeriksaan Payudara Sendiri (SADARI) Sebelum Dan Sesudah Diberikan Penyuluhan Di RW 05 RT 08 Kelurahan Sawunggaling Surabaya Pada Tanggal 11 Mei 2016

Hasil uji statistik didapatkan nilai $\mathrm{p}=$ 0,000 oleh karena $\mathrm{p}<\alpha$, maka terdapat peningkatan pengetahuan tentang cara pemeriksaan payudara sendiri (SADARI).

\section{Pembahasan}

Berdasarkan hasil penelitian sebelum penyuluhan untuk tingkat pengetahuan kurang data yang menindasi didapatkan 8 responden (24\%) memiliki pengetahuan kurang. Apabila ditinjau dari faktor pendidikan terdapat 4 responden $(50 \%)$ berpendidikan SD dan SMP. Menurut Mubarak (2012 :83) bahwa jika tingkat pendidikan seseorang rendah maka akan menghambat perkembangan sikap seseorang terhadap penerimaan informasi dan nilai-nilai yang baru diperkenalkan. Peneliti berpendapat bahwa terdapat kesesuaian antara teori dan fakta dimana seseorang memiliki tingkat pendidikan yang rendah akan berdampak pada pengetahuan yang dimilikinya. Orang yang memiliki tingkat pendidikan menengah kebawah memiliki daya tangkap yang belum maksimal dan pengetahuan yang dimilikinya sempit sehingga berpengaruh terhadap pengetahuan 
yang dimilikinya. Selain itu, apabila dilihat dari faktor pernah mendapatkan informasi terdapat 6 responden $(75 \%)$ tidak pernah mendapatkan informasi. Menurut Mubarak (2012:84) kemudahan untuk memperoleh suatu informasi dapat membantu mempercepat seseorang untuk memperoleh pengetahuan yang baru. Peneliti berpendapat bahwa terdapat ketidaksesuaian antara teori dan fakta hal ini disebabkan karena responden belum mendapatkan informasi sehingga memiliki pengetahuan yang kurang dan akan berpengaruh terhadap pengetahuannya yang mengakibatkan terbatasnya pemahaman serta wawasan seseorang terhadap pengetahuan yang dimilkinya.

Selain data tersebut untuk tingkat pengetahuan cukup dan baik. Ditinjau dari tingkat pendidikan terdapat 15 responden (78,94\%) yang memiliki tingkat pengetahuan cukup berpendidikan SMA dan PT, sedangkan responden yang memiliki tingkat pengetahuan baik terdapat 5 responden (83,33\%) yang berpendidikan PT dan SMA. Menurut Mubarak (2012 :83) bahwa semakin tinggi pendidikan seseorang semakin mudah pula mereka menerima informasi, dan pada akhirnya makin banyak pula pengetahuan yang dimilikinya. Terdapat kesesuaian antara fakta dan teori bahwa responden yang memiliki tingkat pendidikan menengah atas dan perguruan tinggi lebih muda untuk menerima sesuatu sehingga wawasan lebih luas dan lebih memiliki pemikiran yang optimal sehingga mereka mampu menjawab pertanyaan yang diberikan tentang cara pemeriksaan payudara sendiri (SADARI). Selain itu, apabila dilihat dari pernah mendapatkan informasi terdapat 14 responden $(70 \%)$ berpengetahuan cukup dan 4 responden $(20 \%)$ berpengetahuan baik pernah mendapatkan informasi baik dari petugas kesehatan, media elektronik, media cetak dan teman. Menurut Mubarak (2012:84) kemudahan untuk memperoleh suatu informasi dapat membantu mempercepat seseorang untuk memperoleh pengetahuan yang baru. Menurut peneliti terdapat kesesuaian antar teori dan fakta dimana responden yang pernah mendapatkan informasi memiliki pengetahuan cukup dan baik. Informasi yang diperoleh seseorang dapat memberikan pengaruh besar terhadap pengetahuan atau pemahaman mengenai sesuatu. Dengan seringnya mendapatkan informasi dan mudahnya untuk mengakses informasi akan membantu membentuk pengetahuan yang baru selanjutnya dapat meningkatkan kualitas pengetahuan yang dimiliki.

Berdasarkan hasil penelitian sesudah dilakukan penyuluhan ditinjau dari tingkat pendidikan terdapat 6 responden $(50 \%)$ yang memiliki tingkat pengetahuan cukup berpendidikan SMA dan PT, sedangkan responden yang memiliki tingkat pengetahuan baik terdapat 17 responden (85\%) yang berpendidikan PT dan SMA. Menurut Mubarak (2012:83) bahwa semakin tinggi pendidikan seseorang semakin mudah pula mereka menerima informasi, dan pada akhirnya makin banyak pula pengetahuan yang dimilikinya. Terdapat kesesuaian antara fakta dan teori bahwa responden yang memiliki tingkat pendidikan menengah atas dan perguruan tinggi lebih muda untuk menerima, memahami dan mengelolah informasi tentang SADARI yang diberikan melalui penyuluhan kesehatan, karena selama pendidikan mereka sering mendapatbimbingan sesuatu hal yang baru dan ini melatih kemampuan berpikir mereka.

Hasil uji statistik dengan menggunakan Willcoxon test dengan tingkat signifikan $\alpha=$ 0,05 didapatkan harga $p=0,000$. Selain itu nilai $\mathrm{Z}$ juga menunjukkan Zhitung $=-3.752$ dan Ztabel $= \pm 1,96$. Karena $\mathrm{p}<\alpha$, maka $\mathrm{H} 0$ ditolak dan $\mathrm{H} 1$ diterima, sehingga dapat disimpulkan bahwa ada pengaruh tingkat pengetahuan (tahu) tentang cara-cara pemeriksaan payudara sendiri pada ibu-ibu PKK sebelum dan sesudah diberi penyuluhan, dimana tingkat pengetahuan ibuibu PKK lebih baik dan meningkat setelah diberikan penyuluhan. Menurut Machfoedz (2007:53), penyuluhan kesehatan merupakan kegiatan pendidikan kesehatan yang dilakukan dengan menyebarkan pesan, menanamkan keyakinan, sehingga masyarakat tidak saja sadar, tahu dan mengerti, tetapi juga mau atau bisa melakukan suatu anjuran yang ada hubungnnya dengan kesehatan dan Menurut Green yang dikutip oleh Notoatmodjo (2012:22) bahwa pendidikan kesehatan atau promosi kesehatan ditujukan untuk menggugah kesadaran, memberikan atau meningkatkan pengetahuan masyarakat tentang pemeliharaan dan peningkatan 
kesehatan baik bagi dirinya sendiri, keluarganya maupun masyarakat. Menurut peneliti terdapat kesesuaian fakta dan teori dimana sesudah penyuluhan atau pemberian informasi terjadi peningkatan pengetahuan responden dimana dari hasil uji Wilcoxon menunjukkan ada pengaruh positif dalam pemberian penyuluhan sehingga dapat meningkatkan pengetahuan ibu-ibu PKK, hal ini dikarenakan metode ceramah pada saat penyuluhan ada kesempatan bagi responden untuk melakukan tanya jawab jika ada yang kurang jelas.

\section{Simpulan dan Saran}

Hasil penelitian menunjukkan penyuluhan memberikan dampak terhadap peningkatan pengetahuan ibu-ibu PKK tentang cara pemeriksaan payudara sendiri (SADARI).

Setelah mengetahui dari hasil penelitian yang menunjukkan bahwa penyuluhan dapat meningkat pengetahuan, maka peneliti memberikan saran kepada ibu kader kesehatan di Kelurahan Sawunggaling Kecamatan Wonokromo Surabaya dapat bekerja sama dengan petugas kesehatan dari Puskesmas Jagir untuk memberikan penyuluhan kesehatan tentang cara pemeriksaan payudara sendiri (SADARI).

\section{Daftar Pustaka}

Arikunto, S. (2013). Metodelogi Penelitian ilmu KeperawatanPenelitian Suatu Pendekatan Praktik. Jakarta: Salemba Medika

Bickley, Lynn S. (2009). Buku ajar pemeriksaan fisik \& riwayat kesehatan Bates. Alih Bahasa: Esty Wahyuningsih. 2012. Edisi 8. Jakarta: EGC

Black, Joyce M. (2009).Keperawatan Medikal Bedah: Manajemen Klinis untuk Hasil yang di Harapkan. Edisi 2. Alih Bahasa: Joko Mulyanto. 2014. Buku 8.Singapore: Elsevier

Budiman dan Riyanto,A. (2013). Kapital Selekta Kuesioner: Pengetahuan dan Sikap dalam Penelitian Kesehatan. Jakarta: Salemba Medika

Depkes. (2009). Buku Saku Pencegahan Kanker Leher Rahim Dan Kanker Payudara Http://www.pppl.depkes.go.id/_asset/_ download/bukusaku_kanker.pdf

diakses17 februari 2015 jam 09.30 diakses 17 februari 2015 (09.30)

Fitriani, Sinta. (2011). Promosi Keshatan. Yogyakarta: Graha Ilmu

Hidayat, Aziz A. (2010). Metode Penelitian Kesehatan: Pradigma Kuantitatif. Jakarta: Salemba Medika

Hidayat, Aziz A. (2009). Metode Penelitian Keperawatan dan Teknik Analisis Data: Jakarta: Salemba Medika

Hidayat, Aziz A. (2007). Riset Keperawatan dan Teknik Penulisan Ilmiah. Jakarta: Salemba Medika

Richardson.T.(2009)http://mawarmerahmoza ik.wordpres.com/2011/12/16/pentingn ya-periksa-payudara-sendiri-sadaripada-remaja-putridiakses 18 september 2011

Machfoedz, I. (2007). Pendidikan Kesehatan Bagian dari Promosi Kesehatan. Yogyakarta: Penerbit Fitramaya

Maulana, H. (2013). Promosi Kesehatan. Jakarta: EGC

Mubarak, Wahid I. (2012). Promosi Kesehatan: Sebuah Pengantar Proses Belajar Mengajar. Yogyakarta: Graha Ilmu

Mubarak, Wahid I. (2007). Promosi Kesehatan: Sebuah Pengantar Proses Belajar Mengajar. Yogyakarta: Graha Ilmu

Ningsih, T. N. (2014). Tingkat Pengetahuan Wanita Usia Subur Tentang Kanker Payudara. 1. Diakses dari http://www.01-gdl-tutiklesta-725-1tutikle-5

Nisman, Wenny A. (2011). Lima Menit Kenali Payudara Anda. Yogyakarta: Andi

Notoatmodjo, S. (2012). Promosi Kesehatan dan Perilaku Kesehatan. Jakarta: Rineka Cipta

Notoatmodjo, S. (2010). Ilmu Perilaku Kesehatan. Jakarta: Rineka Cipta

Nursalam \& Efendi, F. (2008). Pendidikan dalam Keperawatan. Jakarta: Salemba Medika

Nursalam. (2013). Metodologi Penelitian Ilmu Keperawatan: Pendekatan Praktis.Jakarta: Salemba Medika

Septiani S. (2013). Faktor yang Berhubungan Dengan Perilaku Pemeriksaan 
Payudara Sendiri (SADARI). Jurnal Ilmiah Kesehatan, 5(1,), 31.

Setiadi. (2007). Konsep dan Praktik Penulisan Riset Keperawatan. Yogyakarta: Graha Ilmu

Sugiyono. (2014). Metode Penelitian Kuantitatif dan Kualitatif. Bandung: Alfabeta

Wawan, A dan M, Dewi. (2010). Teori \& Pengukuran Pengetahuan, Sikap dan Perilaku Manusia. Yogyakarta: Nuha Medik

Purwanto, H. (1994). Statistik untuk Keperawatan. Jakarta: EGC 